\title{
Institutionalizing Inequality: Calculative practices and regimes of inequality in international development
}

\section{Please cite as:}

Hayes, N., Introna, L.D. \& Kelly, P. (2017) Institutionalizing Inequality: Calculative practices and regimes of inequality in international development, Organization Studies, Forthcoming.

Niall Hayes, Lancaster University, UK, n.hayes@lancaster.ac.uk

Lucas Introna, Lancaster University, UK, l.introna@lancaster.ac.uk

Paul Kelly, Lancaster University, UK, p.kelly@lancaster.ac.uk

\begin{abstract}
This paper focuses on the institutionalisation of inequality in relations between donors and NGOs in the international development sector. We argue that these relations operate within a neoliberal and competitive marketplace, which are necessarily unequal. Specifically, we focus on the apparently mundane practice of impact assessment (IA), and consider how this is fundamental to understanding the performative enactment of institutional inequality. For our analysis we draw upon Miller and Rose's work on governmentality and calculative practices. We develop our argument with reference to a case study of a donor driven IA initiative being conducted in India. Specifically, we consider an IA initiative that the donor has piloted with one of the NGOs they fund that seeks to improve the livelihoods of Indian farmers. We will argue that institutional inequality can be understood in the way the market as a social institution becomes enacted into mundane calculative practices. Calculative practices produce different kinds of knowledge and in so doing becomes a way in which subjects position themselves, or become positioned, as unequal.
\end{abstract}

Keywords: international development, impact, inequality, calculative practice, governmentality

\section{INTRODUCTION}

Within the international development sector, governments and other donor organisations increasingly require nongovernmental organisations (NGOs) to account for their impact. Impact assessment (IA), the focus of this paper, typically seeks to identify and evaluate a development 
project at specific milestones achieved against the project aims. For donors, IA informs decisions about whether to continue to fund specific projects and how to prioritise their future development activities. Some scholars have noted that management knowledge such as IA has become increasingly widespread across the sector (Banks \& Hulme, David, 2012; Rankin, 2001). Critics have argued that such managerial knowledge is donor centric and has led to asymmetries in power between donors, NGOs and beneficiaries (Hayes and Westrup, 2012). However, this literature has thus far failed examine critically how IA is implicated in institutionalising inequality between donors and NGOs. This is the focus of our paper.

While not directly about IA, Dar's (2014) study of written NGO reports highlighted that top-down reporting leads to disempowerment amongst NGO workers. She argues that as the reports are required to be written in English, this privileges English speaking donors and NGO staff (in her case the aspirational Indian Middle class). Scholars have also noted that western knowledge such as reports are viewed as superior to non-western knowledge such as stories (Dar, 2014). Further, others have argued that western management techniques are imposed on the global south which precludes input from southern actors (Contu and Girei (2013)(Dar, 2008). This leads to decisions about funding projects being based on assumptions that are disconnected from local settings (Riddell (2008)(Hayes \& Westrup, 2012). It also leads to NGO workers mimicking western forms of accountability (Dar, 2014; Hayes \& Westrup, 2012). Critics have argued that much work is expended by NGOs professionalizing' and meeting donor requirements, and in producing the evidence of their impact, leaving them with less time to work with beneficiaries (Strathern, 2003). Evidencing impact also diverts the budget away from beneficiaries towards inhouse or external experts (Roberts, Jones III, \& Fröhling, 2005). Further, as Dar (2014) highlighted, project reporting is often overstated by NGOs in order to attract funding from the same or future donors. This literature seems to suggest that western managerial knowledge, especially produced through quantitative metrics, can disempower NGOs in significant ways.

Impact assessment can of course be seen within the wider landscape of attempts to manage organizational practices by transforming them into calculations that can render them comparable, in some way. Central to this approach of managing-or, this 'governing technology', one might say-is the neoliberal notion that resources are allocated optimally in more or less competitive markets. A commonly used technology to create such competitive markets are ranking and league tables. While the literature on rankings and international development is limited (Mühlen-Schulte, 2012), there has been a considerable discussion of rankings in other sectors such as education (Collins \& Park, 2015; Hardy, Heimans, \& Lingard, 2011; Morrissey, 2013), government (Hansen \& Mühlen-Schulte, 2012), and consulting (Pollock \& D'Adderio, 2012). Overall, scholars highlight that while rankings appear to provide objective measures, that seem to facilitate comparability and competition, they are in fact profoundly political (Espeland \& 
Sauder, 2007; Espeland \& Stevens, 2008). In relation to their research of University Law Schools, Sauder and Lancaster (2006, p.130) claim that rankings affect changes in morale, staff recruitment, and retention. Rankings are also claimed to produce gaming strategies where institutions such as universities make decisions about their investment and admissions criteria so as to enhance their positions in their league tables (Clarke \& Knights, 2015). Espeland and Sauder (2007, p.11) describe rankings as reactivity mechanisms, which are "patterns that shape how people make sense of things... how attention is distributed, and the interactive scripts people adopt." They further note that they not only "exhibit a constant 'surveillance' or presence in/over the higher education environment, but they have become a 'self-disciplining' force." What Espeland and Sauder and others highlight is that rankings shape actors behaviors and understandings of what is valued, and as such have strong self-disciplining outcomes for those who become reflected in them (Bowman \& Bastedo, 2009; Davis, Fisher, Kingsbury, \& Merry, 2012). Further, not only have rankings become an industry themselves, they have spawned new roles within organizations, and new subsectors, that advise their clients on how to improve their position in the matrices that constitute the ranking algorithm (Pollock \& D'Adderio, 2012). Overall, this literature has highlighted that rankings come to shape what people do, how they understand their role, and in doing so, normalise everyday activity. This aligns closely with our argument, in relation to governmentality and inequality. In our discussion below, we want to show how IA (in the development context) and rankings (more generally) function as calculative practices that play a very specific role in institutionalizing, not only the neoliberal logic, but also regimes of inequality. To do this we will draw on the ideas of governmentality, which refers to the way certain actions may structure the field of possible actions available to others.

In sum: the overall aim of this paper is to understand the institutionalisation of inequality in relations between institutions operating in the international development sector. Specifically, we are concerned with the ways in which IA methodologies configure the relations between different institutional actors and how this produces and reproduces institutional inequality across the international development sector. To do this we explore two research questions: (1) what is the role of impact assessment in shaping institutional inequality between institutional actors in the development sector? (2) How are these asymmetrical relations enacted in everyday practice? To answer these questions, we will argue that we need to attend to the ways in which practices of inequality become enacted through, and emerge from, mundane organisational practicesspecifically, calculative practices. Our empirical setting reports on a UK based philanthropic donor (Imagine) that funds an Indian NGO to work with rural farmers to improve their livelihoods. Specifically, we will focus on a project to develop an impact assessment methodology to better identify and measure the impact of their funding. We focus on the ways in which the mundane practices associated with the recording of impact by an Indian NGO modify, or configure, the field of possible actions available to all the actors involved. In our 
analysis, we will show how mundane attempts at governing action enact regimes of inequality. This becomes very significant as these regimes of inequality-that become more or less institutionalised as legitimate governing practices-become adopted as 'good practice' in the development sector.

The next section reviews some of the relevant literature on inequality and institutions. We then outline our theoretical orientation, regarding governmentality. Section 4 outlines the case study and our methodological approach. Section 5 discusses the analytical themes specifically in relation to governmentality and calculative practices. Section 6 develops our analysis, specifically in relation to inequality. The final section concludes by considering the relations between inequality, institutions and organizational practices.

\section{INSTITUTIONAL INEQUALITY}

The literature in organization studies on inequality is extensive in areas such as corporations, disability, sexual-orientation, age, gender and markets (Barley, 2007;Belliveau, 2011; Huffman, Cohen, \& Pearlman, 2010)-refer to (Acker, 2006, 2012) for a detailed review of this literature, which we will not engage directly here. However, we would want to consider, briefly, the question of inequality with respect to institutional theory, or one might say the institutionalisation of inequality.

Institutional theory has not been entirely silent on the matter of inequality-although most of the significant contributions has not been in management and organization studies literature. There is a significant literature on institutional inequality that has focused on inequality in the form of institutional discrimination, especially in terms of gender and race. For example, in her paper on racial bias in medical treatment Bowser (2000, p.371) defines institutional racism as 'those self-perpetuating patterns and practices made in reliance on taken-for-granted background knowledge about race that serve to lower a particular racial group's status.' (Haney Lopez, 1999), in his study of grand juror selection by judges in California identifies two ways in which these self-perpetuating patterns operate: what he calls 'scripts' and 'paths'. He shows how judges unconsciously use the 'pick your friend' script to select their acquaintances as grand jurors. When challenged about their selections they tended to follow established 'paths,' which emphasizes background understandings and established grammars, to constrain their decisions. For example, in such situations they often invoke the established path of 'selecting the best qualified jurors' to constrain their selection practice such that they end up selecting their acquaintances, and excluding certain racial groups-and in so doing unintentionally enact and perpetuate what he calls racial institutions.

(Albiston, 2009), in her study of gender inequality in the workplace, suggests that workplace institutions incorporate historical social practices that presumed women would be marginal 
workers and would occupy subordinate roles in both the workplace and family.' She warns that researchers should not only consider the way in which certain work practices came to be taken for granted, but should also focus on how the meanings of those practices are deeply embedded in the social conditions that accompanied their historical development. Thus, she suggests, that institutions are not primarily important because they encourage or limit the operation of unconscious prejudice, assumptions, bias, etc. Rather, they are important because they embody specific, historically determined, identity conceptions, as in the case of gender and race. What we see, in her work, is a shift of focus away from the practices of institutional actors (their taken for granted assumptions, believes, biases, etc.) to certain historically determined conceptions (one might say generally shared and taken for granted knowledge) that tend to organize meaning, apriori, in significant ways. She suggests that even the attempts to explicitly address gender inequality-such as all the employment practices to 'accommodate' pregnancy, for exampleend up reinforcing these historically determined identity conceptions, and as such, institutional inequality. (Martin, 2004) takes this a step further. She argues that these historically determined identity conceptions, such as gender, should be understood as social institutions. She argues that social institutions such as gender persist, shape, and get reenacted through mundane organizational practices - the example to 'accommodate' periods of pregnancy cited by (Albiston, 2009) being illustrative of this. This focus on the importance of the social organization of meaning, expressed as social institutions, is in our view, helpful. The question then becomes how historically determined social institutions such as gender, race, etc. gets translated in and through mundane organizational practices-such as the 'scripts' and 'paths' that (Haney Lopez, 1999) identified. Before we proceed, however, let us pause to ask why the question of the institutionalization of inequality has not featured in any significant way in the management and organization studies literature? And moreover, if it did become a focus, what would be an appropriate way to attend to it?

One theme that runs through all accounts of inequality is the issue of more or less enduring systematic asymmetries of power and agency. If this is the case, why did institutional theory not engage significantly with power, and in particular with systematic asymmetries of power? One answer to these questions is proposed by (Munir, 2015). He suggests that although institutional theorists are concerned with power, implicitly or explicitly, they are mostly not concerned with its problematic use. He suggests that the growing inequality inside and outside organizations are largely overlooked by institutional theorists, and proposes a more critical approach to account for the 'problematic' use of power. Others might argue that the problem is that power has never been an explicit preoccupation for institutional theory (Clegg, 2010). Indeed, such criticism has also come from within the tradition itself (T. B. Lawrence, 2008; Munir, 2015). Nonetheless, it can be suggested that power has always been implicitly and explicitly present in institutional theory, from the start. In their paper on institutional isomorphism DiMaggio and Powell (1983) 
suggested that their work connects to the question of power in two senses: '[p]ower to set premises, to define the norms and standards which shape and channel behaviour [and the way] elites can define appropriate models of organizational structure and policy which then go unquestioned for years to come' (p. 157). It seems that it is this second sense of power-as more or less intentional and actor-centric - that seem to have become the focus of institutional theory, as reflected, for example, in DiMaggio's (1988) later, and very influential, work on the institutional entrepreneur.

This actor centric view of power-as reflected in the work on the institutional entrepreneurleads to a type of 'hypermuscular agency' (Clegg, 2010) which obscures the mundane organisation practices that renders such an actor possible, or impossible, in the first place. The research on institutional work, with its emphasis on 'the myriad, day-to-day equivocal instances of agency,' attempts remedy this tendency to focus on 'heroic' actors and events (Lawrence, Suddaby, \& Leca, 2011), yet it still focuses on intentional work that is 'aimed at affecting an institution or set of institutions' (p. 53). Others, such as Lounsbury and Crumley (2007) turns to practice theory to make visible the more emergent, spatially dispersed, and heterogeneous activity by actors that enact institutionalising practices. Specifically, they suggest, in their conclusion, that what is needed is not only attend to actors, as such, but also 'wider meaning systems and theories embedded in cultural elements such as categories, conventions, and discourse'. This is exactly where our contribution will be focused, as we hope to demonstrate below.

More recently, Lawrence (2008) has overtly taken on the criticism that institutional theory does not engage with power in his widely cited chapter Power, Institutions, and Organisations. He argues that power is central to our understanding of how institutions operate. To facilitate such understanding he proposes a framework of three institutional dimensions of power: institutional control, institutional agency, and institutional resistance. Of particular significance for our purpose is the dimension of institutional control. In his discussion of these three dimensions, he explicitly adopts the Foucauldian view that power is relational rather than something that an actor can have, hold, or keep in reserve. Hence, institutional control is understood as the relational effects of institutions on actors-his illustrative example is that of disciplinary power (citing Foucault's work as central to this). In the concluding part of his chapter, he suggests that 'the problem of institutional control is far more complex than current institutional theories can address, and that many of the important details of how institutional control occurs remain to be worked out' (p.187). We concur with this and suggest that our work attempts to do exactly that. More precisely, we would suggest that our empirical case illustrates that there is an intimate connection between the operation of institutional control, and the enactment institutional inequality. This relationship, we will aim to show, can best be understood through the notion of 
governmentality, as expressed in the later work of Foucault (1982) but also developed extensively by Miller and Rose (1990; 2008).

\section{GOVERNMENTALITY}

In our introduction, above, we highlighted an unfolding narrative of attempts to govern the development sector through the use of managerial knowledge, with specific emphasis on impact assessments. In this section, we will outline a particular way to understand these attempts at governing, that is, as governmentality. Governmentality allows us to consider the institutionalisation of inequality in the terms suggested by Lounsbury and Crumley (2007, p. 1007). That is, in terms of 'wider systems of meaning' (neoliberalism, in our case) and in terms of embedded 'categories, conventions, and discourses' (knowledge production through calculative practices, in our case). In his 1982 essay The Subject and Power, under the heading 'how power is exercised' Foucault offers an alternative to the dominant actor-centric adversarial model of power/resistance. He suggests that 'the exercise of power is not simply a relationship between partners, individual or collective; it is a way in which certain actions modify others.' He calls these actions that modify the field of possible actions available to others, government (or governmentality, as it has become defined). This governmental relationship of power does not prohibit, or constrain, it enables, but in specific ways. The actors, situated within this field of possible actions, choose freely to become enacted within the range of possibilities available to them.

Governmentality can be understood through three dimensions, regimes of governance, technologies of governance and calculative practices and subjects (Figure 1). For analytical purposes, we will discuss each of these in turn. However, in their practical enactment they are intimately intermeshed and mutually constitutive.

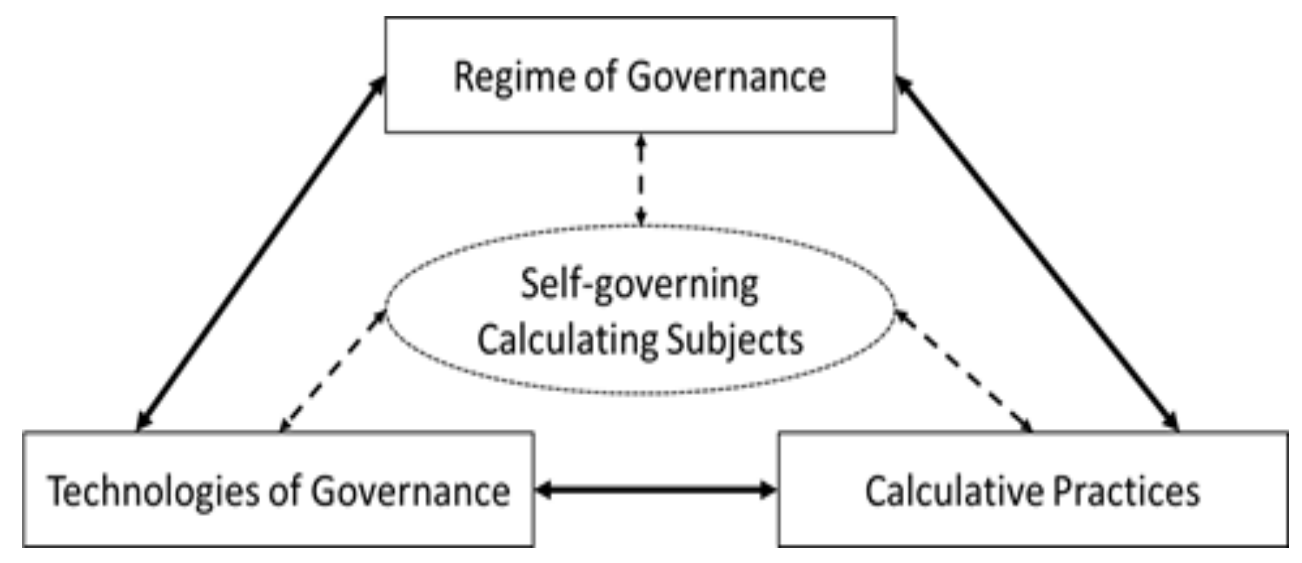

Figure 1: Governmentality

Unlike the traditional practices of management control, which assumes the power and authority to be located and mobilised intentionally, a regime of governance points to the 'conducting of 
conduct.' That is, control that is not externally imposed but is the result of a multiplicity of more or less autonomous, but interdependent, actors or institutions shaping conduct through a taken for granted logic or rationality. According to Foucault, and others, the dominant taken for granted logic or rationality, in the West, has become neo-liberalism. This is neo-liberalism not only understood as a political economy but the extension of the market logic and values to all spheres of life so as to "reform institutional and individual conduct so they both come to embody the values and orientations of the market, expressed in notions of the enterprise and the consumer" (Dean, 2009, p. 201). Dean and others propose that governance is enacted by actors seemingly freely taking upon themselves certain expectations and responsibilities by accepting the taken for granted governing logic (of the market) as natural and self-evident.

How is this conduct of conduct enacted, specifically? This is done through technologies of governance. Rose and Miller (1992, p. 183) explain that technologies of governance aim to establish "a multitude of connections... between the aspirations of authorities and the activities of individuals and groups." More specifically, in order to achieve these connections aspirations and activities such technologies of governance need to enact domains of knowledge and subjects that orient themselves freely according to these 'claims of truth' - that is regimes of truth and selfgoverning subjects. Miller and Rose in their work demonstrated how this is achieved through governing technology, which they refer to as calculative practices.

Miller and Rose (as quoted in Miller (2008, p. 57) suggest that, "calculation... [is] one of the preeminent modalities of making programmes [of governance] operable." Miller (2008, p. 58) in his studies of the calculative practices of accounting - such as double entry bookkeeping, corporate financial reporting and managerial accounting-show how "the single financial figure is a technology of intervention par excellence... [it] not only accords objectivity and neutrality, it makes comparable activities and processes that may otherwise have little in common." Calculative practices enact domains of knowledge (with associated expertise) that constitute regimes of truth. Such regimes of truth can then function to distinguish between 'true' and 'false' statements about the activity being governed. For example, the question of whether a company is financially sound can be determined by reference to accounting and financial data. In such regimes of truth the 'facts' are inseparable from the techniques, mechanisms and rules that constitute them as such.

Once established such calculative practices (with its associated regimes of truth) enact calculative subjects (also referred to as self-governing subjects). As Miller and Rose (1990, p. 18) suggest, in the end "[g]overning operates through subjects." Calculating subjects internalise the regime of truth and orient themselves accordingly-knowledge and expertise becomes translated into the personal capacities and aspirations of these subjects. For example, managers, as calculating subjects, see themselves as responsible for the profitability of the organization and govern their 
own practices accordingly. Further, as Espeland and Sauder have argued, the pervasiveness of rankings in higher education has led to the incremental transformation of HEls "into entities that conform more closely to the criteria used to construct rankings, and prompt[ing] the redistribution of resources, the redefinition of work, and gaming" (2007, p.33). More specifically, in relation to our first research question, it suggests that IA expertise in the development sector, produced through calculative practices such as impact evaluation models, "makes intersubjectivity calculable" (Rose, 1998, p.91). In our case study, we will show how IA, as a technology of governance, enacts domains of knowledge and self-governing subjects. In relation to our second research question, we will argue that these mundane calculative practices lead to relatively unpredictable 'consequences, effects, and outcomes'. Further, we will argue that such outcomes are framed within a neo-liberal logic of competition and markets.

The neo-liberal logic of the market has as its most basic mechanism competition, the cultivation of differential relational inequalities. These relational inequalities enact the market but also the enterprising subject. In these unequal or dissymmetrical relations actors are always in the position of simultaneously being enacted (through unequal relations of power) and exercising power (drawing inequalities to act). Differently stated inequality circulates. Tracing this circulation of dissymmetry or inequality, specifically, is our ethico-political task, as suggested by Foucault: "My point is not that [inequality] is bad, but that [it] is dangerous, which is not exactly the same as bad. If [it] is dangerous, then we always have something to do. So my position leads not to apathy but to a hyper- and pessimistic activism. I think that the ethico-political choice we have to make every day is to determine which is the main danger" (Dreyfus \& Rabinow, 1983, p. 231). We will do this by tracing the circulation through the situated operation of mundane calculative practices-what Foucault calls the micro-physics of power-enacted in an attempt to govern international development activity in India.

\section{THE IMAGINE FOUNDATION}

In order to understand the role of IA in shaping inequality in relations between institutional actors in the development sector, we report on a case study of a UK based philanthropic donor (Imagine). Imagine is a grant-making organization that funds "efficient and impact-driven models of development" and actively engages with the NGOs they fund so as to assist them in achieving their goals and "measurable results". Imagine is owned by Vijay, a London based venture capitalist. In conjunction with an Indian NGO (Rural India), Imagine funds activities with rural farmers. As part of their development of this programme, they initiated a project to develop an IA methodology to better identify and measure the impact that their funding has. This took the form of a survey that captured key performance metrics relating to 10,000 rural farmers. The survey included predominantly closed question fields (amounts, yes/no answers, and limited choice responses) that charted performance indicators such as family unit size, changes in 
income, crop based agriculture and livestock farming, children's education, and housing facilities. A spreadsheet was developed and tablets provided. NGO field workers and local village volunteers used mobile tablet computers loaded with survey software to conduct surveys in villages and farmers' houses. After conducting the surveys, field workers returned the devices back to NGO offices and uploaded the survey data onto an office computer for storage and later analysis by NGO staff. In the past, data had been manually entered into the central computers.

\section{Research Methodology}

Our programme of empirical work was undertaken between April 2013 and March 2014. Imagine approached the authors seeking advice about developing their existing IA assessment processes. At the outset, Imagine requested that we be involved in reviewing their evaluation approach and providing suggestions for change. We agreed that initially we would familiarise ourselves with their past and current practices before we intervened directly. However, after eight months our key contact in Imagine moved onto another project and our communication with the NGO gradually petered out. Without the direct access mediated by the donor, the NGO gradually stopped responding to our questions for further meetings and data. While we do not know why exactly, it is reasonable to assume that this review was not something the NGO saw as immediately beneficial to them. Thus, while initiating the project as an action research project, in effect has been an interpretive case study (Walsham, 1995).

In relation to our primary data collection, we undertook a total of ten telephone / Skype interviews over this eleven-month period. Interviews were conducted with Vijay, the venture capitalist, Leonard, the project manager, Chandan (the NGO director) and several other NGO staff. Some of the interviews were conducted on a one-to-one basis, while others were group calls between several participants. All interviews were semi-structured and lasted typically between one and two hours. Interview questions centred on the rationale for introducing the IA project, the problems they had encountered, the different roles, the collection of impact data, the spreadsheets and the qualitative impact data. Interviews were recorded and transcribed. A number of follow-up interviews were undertaken so as to clarify issues or to ask further questions. Our primary research was limited due to the difficulties already mentioned in relation to securing access. We were granted access through the donor and as such we were conscious throughout that we were viewed by the NGO as being aligned with the interests of the donor. This may have shaped the nature of their responses, but also relations with the NGO once our key contact at the donor changed role. Secondly, we sensed that the donor had not appreciated the time that our study would take. He had primarily invited us thinking we would be able to quickly redesign the spreadsheet questions and to also specify some changes to the tablet PC's that were used to collect the impact data. A further limitation related to the number of NGO staff that we were able to interview. As, English was not spoken by many of the NGO staff, 
volunteers and beneficiaries, interviews via Skype were not feasible. Further, though we planned a research visit to India to meet a wide range of NGO staff and beneficiaries, this was curtailed by the NGOs gradual withdrawal from the research.

In relation to secondary data, Imagine provided us with 2000 survey responses from the previous eight years. They also provided us with the impact spreadsheets that this data was inputted into. We also collected project documentation, reports and brochures. We discussed this secondary data during interviews with donor and NGO staff. For example, we would ask about the categories chosen in the spreadsheet, any changes that had been made, their training programmes, the selection of locations, the organisation of staff and volunteers and the data collection process.

We analysed our data manually. At the end of each interview we listed themes that were emerging, then transcribed the interviews, and reconsidered the themes once more. Themes were also compared between interviews. Our particular focus was on understanding the ways in which IA shaped the relations between the donor and the NGO. We gradually organized them into broader themes (Alvesson \& Skoldberg, 2000)(Strauss, 1987). In terms of the secondary data, we looked for themes in the brochures and reports, and produced summary reports from the excel spreadsheet. We then considered these themes more specifically with our theoretical commitments, governmentality, and with the literature.

\section{IMPACT ASSESMENT BY IMAGINE}

This section will discuss how IA was enacted with reference to regimes of governance, technologies of governance and calculative practices and calculative subjects.

\section{Impact and its regime of governance}

Government is a problematizing activity: it poses the obligations of rulers in terms of the problems they seek to address. (Rose \& Miller, 1992, p. 181)

A first analytical theme we seek to establish is how this practice of IA in the international development sector is aligned to a dominant regime of governance. Specifically, we want to understand what the problem is for which IA is supposed to be the governing technology. The problematizing activity for neo-liberalism is how to shape institutional and individual conduct so they embody the values and orientations of the market. In this case the market for grant funding from donors. To do this NGOs need to demonstrate their value propositions as impact. Thus, IA becomes positioned as a powerful governing technology-akin to the 'return on investment' methodology used in for-profit organizations. It aims to transform the relationship between resources utilised, and outcomes achieved. In other words, IA allows for the supposed outcomes of development activity to become comparable in a competitive grant or donor seeking market. 
A neoliberal form of governmentality and its discourse of 'return' on resources invested were very evident in our case study. From the donor's perspective, IA was an important way for them to gain a clear and objective insight into the extent to which their funding was having any 'return' in terms of increasing the incomes of farmers in making them self-sufficient. Indeed, in an interview Vijay, the donor, explained that he had been funding Rural India for ten years, providing millions of pounds but was unsure if it actually had a benefit. He said he could not see why Rural India could not account for their impact just as all his for-profit businesses were routinely required to do. He was adamant that some of his existing approaches and technologies could be adapted and used to measure the impact they were having. What he did not articulate, and that which we want to focus on here, is what this particular governing rationality, with its associated technology does, what it enacts, and why it matters.

\section{Technologies of governance \& calculative practices}

Governmentality allows us to shift from what IA is, to what it does, as a particular technology of governance, within a particular governing rationality. Rose and Miller (1992, p. 183) explain that technologies of governance aim to establish " $a$ multitude of connections...between the aspirations of authorities and the activities of individuals and groups." How do the aspirations of Vijay become connected to the activities of the NGOs?

Vijay appointed Leonard to lead the project from London, and to put in place an IA methodology in collaboration with Rural India. Leonard is a senior, trusted, and long serving member of Vijay's for-profit business and would frequently be deployed to initiate new projects. The problem for Leonard was how to translate the activities and associated outcomes (of Rural India and the farmers) to become relevant to the decision making aspirations of Vijay. What Vijay required was a set of technologies that 'grasp' the truth of impact and 'represent' it in a form that allows for 'conscious political calculation' - within the already assumed neoliberal rationality (Rose \& Miller, 1992). In Vijay's discourse this required a methodology that would render visible the impact of his investments-so that decisions can be made about the allocation of resources. Such a methodology called for calculative practices. Miller (2008, p. 179) suggests that calculative practices are the "mechanisms through which programs of government are articulated and made operable." In the case of Vijay it took the form of a spreadsheet (Figure 2), amongst others. 


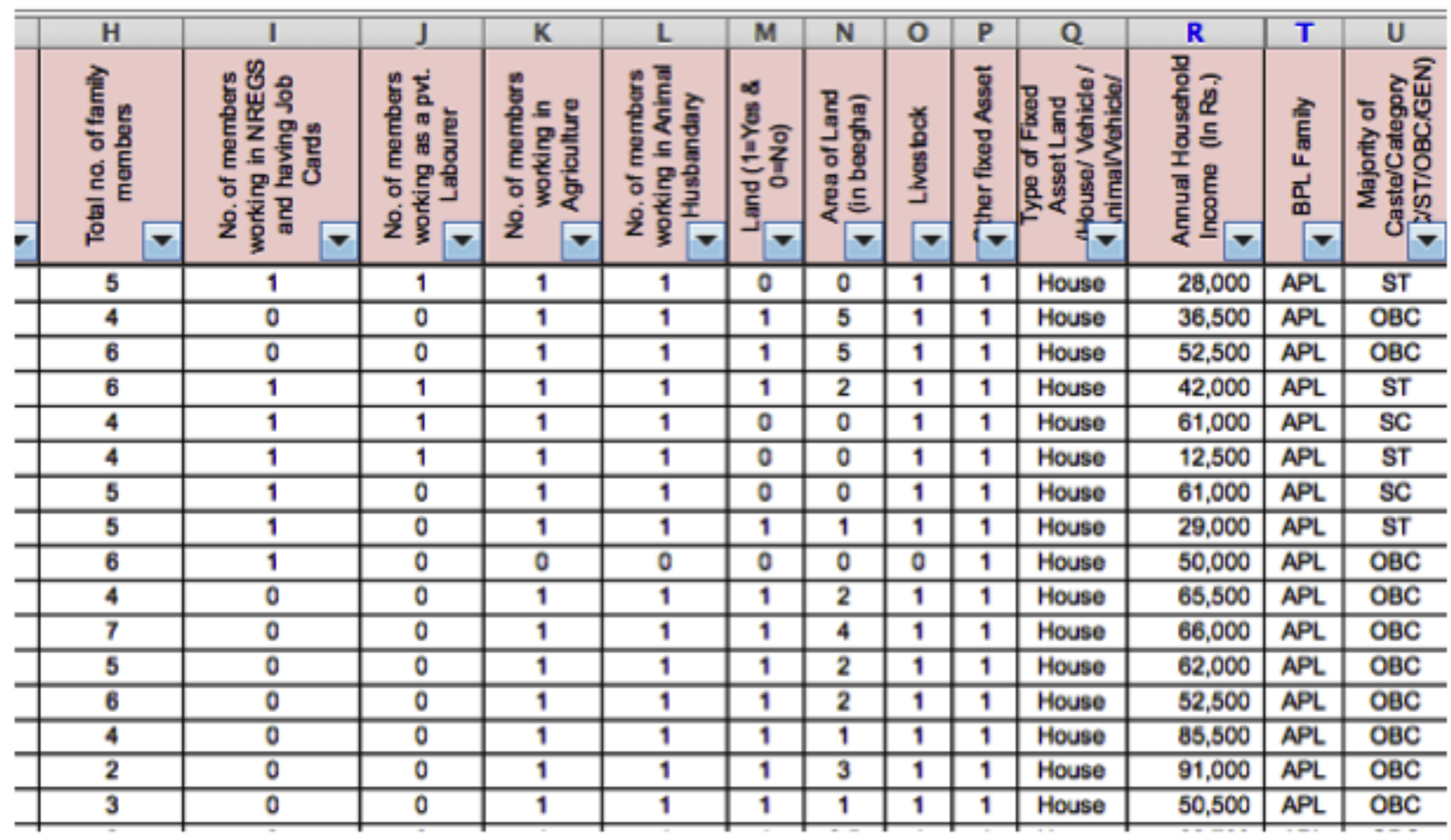

Figure 2: Impact assessment spreadsheet

Spreadsheets allow for the juxtaposition of large amounts of numeric or nominal data that can then be brought into relation with each other. As such, Leonard focused on producing a spreadsheet that would form the core of the IA methodology (Figure 2). Leonard specified many of the fields in the spreadsheet that the NGO was required to complete. The spreadsheet renders development practices visible through specific numbers, such as a farmer's income, housing, sanitation, family size, land size, and their livestock etc. This data can be compared against the impact that was forecast, and the resources provided between farmers, regions and over time. Further, as the donor supports other NGOs, it provides for comparison between one another. Central to the success of the calculating practices was the perceived accuracy of the data. In order to capture the impact data accurately, in situ, Imagine also developed software, implemented on tablets, to capture the data. The software scripted the questions related to impact, which the field workers were required to ask during their interactions with the beneficiaries. The IA methodology and its associated software created a new domain of knowledge that became constitutive of what legitimate impact is (and by implication, how it should be governed) - as Miller (2004, p. 181) observes, "what is counted usually counts."

Discussions between Leonard and Chandan revolved around the fields in the spreadsheet, the impact data and how to make it more rigorous. During these discussions, Leonard would sometimes question the NGO's work and intervene directly by asking for new fields in the spreadsheet, or voicing the priorities for how and why technology and software was required: 
"The first thing is just to test ... test how the technology can help. We want to ... $y^{\prime}$ know so that it gives valuable information faster, to add value and so we can understand what's really happening. ... Obviously the technology is a tool for capturing ... better ... and faster ... and analysing the data--that is the key."

What is 'really happening' is now what is represented in the spreadsheet, through its fields and associated calculative practices. The knowledge constituted through these calculative practices made governing operable, and constituted the relations between donor and NGO staff. The donor in London was able to make judgements about impacts that its funding was actually having on beneficiaries. The NGO staff and the volunteers were required to account for their development activities through the numbers they entered into the spreadsheet. The importance of the data was also made visible by the attention it was given by the donor. As such, the NGO set up training programmes that explained the importance of impact data, and the questions that they had to ask the beneficiaries, and how to use the tablet. Rose and Miller (1992, p. 183) suggest, "[w]e need to study [these] humble and mundane mechanisms by which authorities see to instantiate government..." Thus, what we see is that through these routine practices of training and data collection, the IA methodology becomes positioned as a powerful technology of government, in spite of its seemingly mundane character.

The legitimacy of the donor's knowledge claim to expertise, deriving from their experience of evaluating impact in their for-profit businesses, was taken as self-evident. It was seen as entirely legitimate that the donor should define the IA methodology and the associated systems for capturing data. The donors acted as the assessor of impact, while the NGO was primarily the collector of data. What we see is that all the actors become implicated in the technology of governance. As they invest more of themselves in it, as calculating subjects, they also have an interest in maintaining its legitimacy. Even when impact data was uncertain and sometimes inaccurate, it was still collected. As Chandan explained in a number of ways:

"We know the family size, landholdings but not exact figures for savings and expenditure ... because they are not very exact, they don't record their expenditure as they sell their produce, they get the money and they finish the money in a day. They don't know how they have spent it."

"... population density is high and there are a lot of disturbances, so when I am asking you a question there will be a few others, their neighbours all clamouring there, answering questions and disturbing and all that."

Such anomalies did not render the governing technology, and the regime of truth it enacted, as perhaps inappropriate. Rather, such challenges are treated as practical problems that need resolving such as, refining the spreadsheet, and providing better training for those collecting 
impact data.

\section{Self-governing subjects and qualitative impact data}

Above it was suggested, that the calculative practices enacted a particular regime of knowledge or truth that defined what counted as development, and what did not-a regime that assumed a neo-liberal logic as self-evident. Alternative domains of knowledge existed. The staff of the NGO, volunteers, and farmers had a situated, tacit understanding of what was happening 'on the ground', as it were, and which could potentially have challenged the dominant regime of truth. This knowledge could have been narrated by the actors as valid stories of how lives were impacted, or changed, because of the development activities of the NGO. Such qualitative accounts might have offered the actors involved an opportunity to make some of their knowledge and expertise visible in order to create a counter discourse of legitimation. As such, the researchers asked the NGO staff whether they collected more qualitative accounts of the impacts of their development activities. They suggested that they indeed had a whole database full of case stories of how their development work was affecting the community. As an example, they offered the story or vignette of Devi, a farmer in Rajasthan, describing her participation in a project (Figure 3).

Case Story 6:
My name is Devi. My husband's name is Ram and I am a resident of
Alwar District in Rajasthan. There are 4 members in my family and the only livelihood source for
us is agriculture. Even after continuous hard work, the economic condition of my family is very
poor. One day, the project staffs from Farmers' Club Project
informed her about the benefits of becoming part of the project. Initially, I was not convinced
but observing the benefits received by other women of the community, I became a member of
S ji livelihood group.
I started following improved agriculture practices in Mustard in the area of 3,750 sq. m. under
the technical guidance of HPPI. The practices involved proper seed treatment, application of

Figure 3: Farmer vignette from NGO report

This excerpt of the story is very revealing, but not for obvious reasons. What is interesting about the vignette is its correlation with the data in the impact spreadsheet. It seems that these stories were constructed by narrating the numbers in the spreadsheet. In other words, they were constructed to create a consistency between the quantitative impact data and the qualitative stories. Why would they do that, and risk delegitimising their own situated knowledge? One reading of this would be that they have become self-governing subjects. By that we mean that 
they have accepted fully the validity of the governing technology, with its associated regime of truth. They felt it necessary to narrate the qualitative stories in terms of the quantitative data, in order to legitimate these accounts.

Beyond these stories, there was a belief that more 'qualitative' data was necessary. As such qualitative interviews were conducted, in situ, using a fixed interview protocol as shown in Figure 4. Again, what we see is a set of questions that have Boolean or multiple-choice answers, which are more amenable to calculative practices (of counting and ordering). This design of the protocol is partly informed by the fact that the field workers had limited skills (and time) to capture more unstructured qualitative data. Nevertheless, it was also significantly shaped by what is seen as legitimate data in the regime of governance. This is despite the fact that Leonard repeatedly expressed the need for beneficiaries to have more opportunities to narrate their own stories. For example, he suggested they do not just want to know that a farmer sells his goods in the market; other data would also be helpful:

\section{"... if you sell in the market, then what is the process? How do you sell? Do you, do you yourself go there? I want him or her to kind of, say more on this."}

What Leonard did not appreciate is the manner in which the governing technology had become internalised by the subjects it was supposed to govern. While he could imagine different data, which could tell a different story, for the NGO staff, as calculative subjects, IA became the way they legitimated themselves, their work, and their requests for resources. For them, as calculative subjects, they had to count, and to make what is counted count.

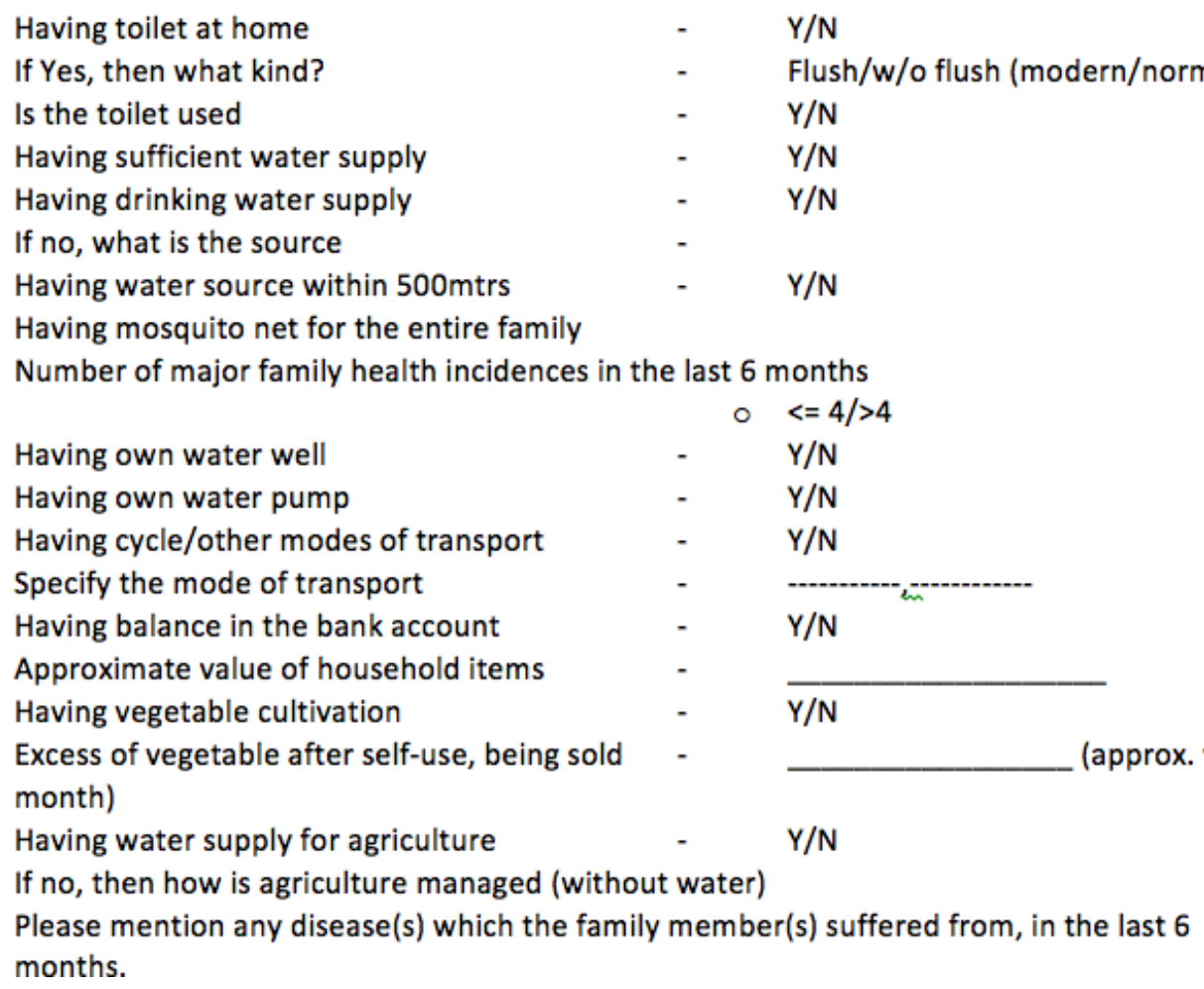


Figure 4: Qualitative interview protocol

\section{Becoming knowledgeable in the enactment of impact}

Becoming self-governing subjects means that power has now become internalised as a particular way one should be, legitimated by a regime of knowledge that constrains, but also enables. Within such a domain of knowledge, one can become an expert. Such expertise can be used in pursuit of what is assumed to be one's own objectives or interests. As such, the NGO started to become more skilful in using the assessment practices and results to impress the donor in an attempt to secure further funding. When asked to implement the IA method, the NGO identified an area close to Delhi that they knew was going to highlight their positive impact, given the governing technology. Indeed, they referred to this as a 'model district.' It was a 'model', not in general terms, but in terms of that which was counted in the spreadsheet. They knew that it would look good through the calculative practices of the impact model. Chandan, described how the overriding purpose of the assessment operation was akin to a sales pitch, and thus informed both research and later lobbying activities.

"... we need to present it to prospective funders, fundraising events etc... we have moved the community from point $x$ to point $y . .$. we chose those villages that could demonstrate greatest impact in terms of low starting point... So we want to say, hey guys, with the $x$ amount of money that you have put in we have been able to leverage $100 x$...So this is a kind of pitch that we are trying to do on the basis of solid evidence on the ground."

'Solid evidence on the ground' is now what is seen as that which counts, according to the impact model. As the quote above highlights, representing their success, not just to the donor, but to other prospective donors was important. NGO's are often funded simultaneously by several donors, and further, as funding is fixed term, are also aware that they will need to continue to attract alternative donors. Chandan explained how by using a "model district" as a sampling strategy, evidence could be marshalled to support fundraising negotiations.

"we have taken the district as a model district. We want to show case this... that the work has changed the district vis-a-vis the other neighbouring districts. So we want to bring that ... every factor in development."

Indeed, their selection of such a test bed for IA illustrates the NGO were clearly aware of the "before and after" project evaluation that they were subjected to. Their experience and expertise 
in constructing such evidence was a vital part of not only satisfying their current donor (so as to maintain their work with farmers), but also to construct their sales pitch to future donors. Becoming a governed subject was also empowering. It allowed the NGO to enact themselves as 'successful' and competent developers. However, this is in the terms of the governing technology and its governing rational-that is, neoliberalism. In internalising and enacting this governing technology they are becoming particular type of developers and development is becoming a particular type of activity. It is not clear that the actors understand this performativity? What seems to be a mundane practice of IA is transforming development practice-and it seems that all actors are caught up in it in more or less significant ways.

\section{REGIMES OF GOVERNANCE AND REGIMES OF INEQUALITY}

In this section, we will argue that inequality-understood as the circulation of asymmetries of power-in the international development sector can be understood, first through the enactment of a grant seeking marketplace, second, through knowledge/power inequality and subjectivity, and finally, in terms of its performativity (Figure 5).

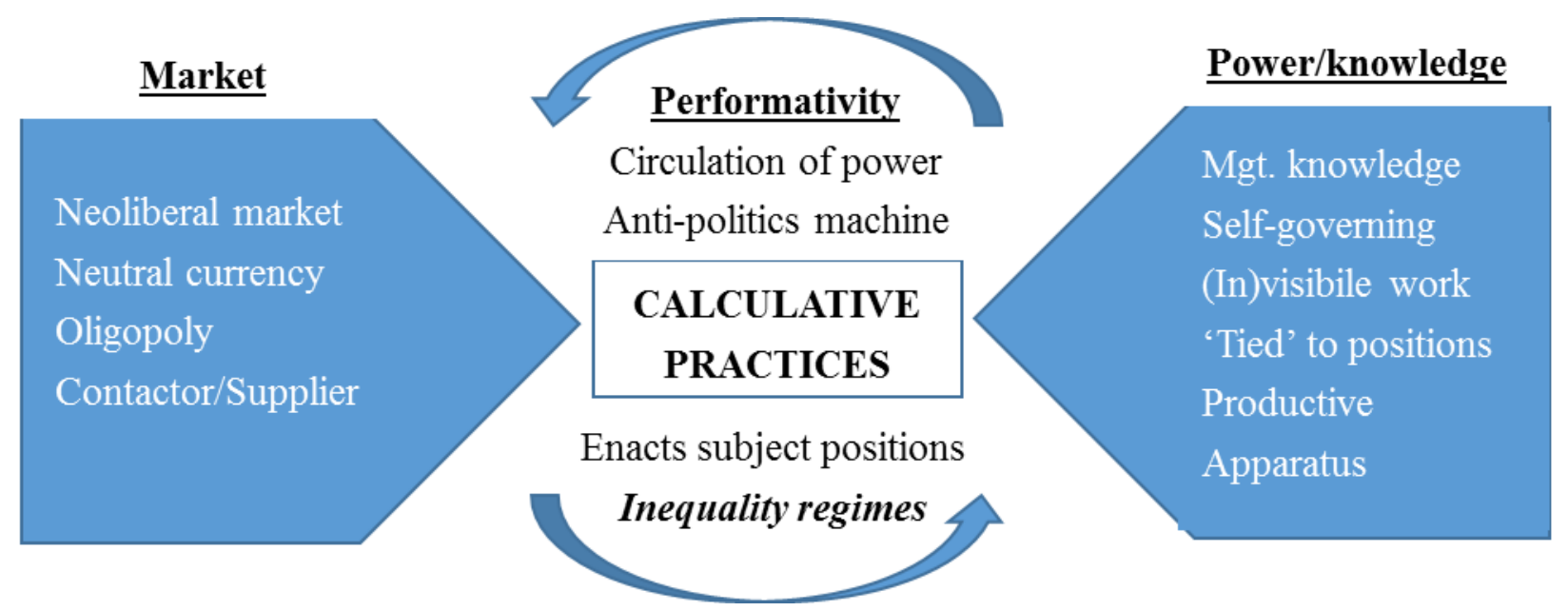

Figure 5: Inequality in the international development sector

\section{The inequality of the market}

Competition will only work, in this marketplace for grant money, if inequalities can be established and constantly cultivated and maintained. It is assumed that without competition, there would merely be exchange between equals, without the discriminating and efficient force of the market. Inequality between actors-enacted as IA-then is the fundamental basis for enacting and governing the grant seeking market. For inequality to circulate, IA must become adopted as a sort of currency. For something to function as a currency, equivalence is required. One unit must be like the other. Calculative practices achieve this equivalence through disembedding entities in the world and enacting them as a quantity (Callon \& Muniesa, 2005; 
Hansen \& Mühlen-Schulte, 2012). A currency also requires the enactment of value. IA enacts value by demonstrating an effect (or a change), which they claim can be attributed ${ }^{1}$ to the development activities of the NGO. Equivalence and value allows for exchange and as a currency, IA is amenable to conscious political calculation.

The circulation of IA as a currency, is intimately connected to the assumed neutrality of the impact data (Miller, 2008). As such, the circulation of inequality becomes seen as legitimateboth necessary and fair. It provided for the comparison of the NGO's impact over time and also the comparison with other NGOs. It meant that any NGOs wanting to compete for grants must adopt it, if they are to claim legitimacy. Accordingly, IA, as a governing technology, has become enacted as fundamental to sector wide competition (The Global Fund, 2011).

In the for-profit sector, markets tend to operate competitively when there is a certain symmetry between supply and demand. In the international development sector, the grant seeking marketplace is very much one akin to an oligopoly, where there are limited demand (donors) and many suppliers of development activities (NGOs). Donors account for about $85 \%-90 \%$ of NGO funding (Banks \& Hulme, 2012). This dissymmetry means that donors can shape the circulation of inequality to a more or less significant degree. It also means that the currency (IA) becomes disproportionately significant for the NGOs - sometimes at the expense of development activities itself. This oligopoly was evident in our case. There were many alternative NGOs that could undertake rural development projects and as such the NGO was aware that the donor could potentially switch their funding to another NGO and/or switch their funding priorities away from rural farming communities. For Rural India, they must demonstrate they are better at doing development than other NGOs and were thus subject to attending to Imagines' requests and requirements. Significant time and resources were invested in demonstrating impact (methodology, training, capturing data, etc.) and 'keeping the donor happy'.

Cumulatively, the establishment of a grant seeking market that can be characterised as an oligopoly, predicated on the currency of impact data, reconfigures relations across the international development sector. This market conceives of the donor as the commissioner (the buyer) of development work and the NGO as the supplier, the implementer of the donor's priorities. Just as with any fixed term contract, donor funding will be renewed subject to satisfactory performance-judged against the impact metrics (Banks \& Hulme, 2012). This

\footnotetext{
${ }^{1}$ Much of the activity associated with the development of impact assessments is concerned with what is referred to as the 'attribution gap'. In other words to demonstrated that there is a direct causal relationship between the activities of the NGO and the development effects achieved. This concern can be seen as a concern with the value claims of the currency (Chambers, 2010)
} 
unequal structuring of relations between donors and NGOs then is a central outcome of the neoliberal regime of governance.

\section{Power/knowledge}

The market-oriented neo-liberal regime of governance privileges managerial knowledge produced by institutions that operate in competitive markets. As such, the knowledge produced by the IA methodology enacted a particular neo-liberal understanding of what successful development was. This knowledge tended to delegitimise the local situated knowledge of the development practitioners within the NGO (Contu \& Girei, 2013). More specifically, this form of knowledge connected directly to the aspirations of those who governed, allowing them to shape the discourse in more or less significant ways-making it operational and available to political calculation (Rose and Miller, 1992).

As privileged knowledge, it becomes internalised and adopted-often implicitly-by the different actors, in pursuit of their own ends. In our case, we saw this internalisation in the way the development practitioners approached qualitative IA by narrating numbers, as if it was a number in a spreadsheet. Thus, regimes of governance and calculative practices enact and cultivate self-regulating subjects that internalise the knowledge, and in so doing, the governing logic of the equal inequality of the market (Rankin, 2001)-and they do this freely. This marketoriented subjectivity more or less displaces or delegitimises some of the original practices, values and meanings of NGOs (Banks \& Hulme, 2012). This is akin to what (Roberts et al., 2005) refer to as subtle paternalism, where northern management knowledge transforms the day to day practices of NGOs in the global south.

The privileged status of this knowledge also renders certain development work invisible and gives prominence to others. This is especially significant when we consider the fact that not all actors are positioned equally in terms of defining the actual calculative practices-as was evident in our case. The donor was able to define the relevant fields in the spreadsheet, train the NGO staff in the methodology, and use technology to ensure compliance with the methodology. This dissymmetry was only possible because the governing logic was already accepted as self-evident by all the actors involved, freely.

As knowledge circulates, it often circulates through, or becomes 'tied' to, specific positionswhich may over time become obligatory passage points. For example, donors and international NGOs have Departments of Impact and Evaluation and staff with roles such as Directors of Impact. In addition, they often pay for consultants who specialise in IA to offer advice, develop impact methodologies and assessments. Through these positions, and their assumed expert knowledge, the self-regulating subjectivity of all the actors involved are further cultivated and 
reinforced (Roberts et al., 2005). These experts become the loci where what counts as good impact are specified and refined. In contrast, NGO managers are typically general managers, and as such do not have such specialist expertise. Nor do they have the same access to the education and training that those working for donors or international NGOs have. These impact experts become valuable resources but also key nodes through which knowledge circulates, unequally.

The unequal circulation of knowledge also enacts a different development subject. One who understands the importance of this impact knowledge and starts to use it productively. In our case, it was clear that the NGO became increasingly knowledgeable about the importance of IA as a currency to be exchanged for their benefit. They started to carefully consider what data was collected and when (e.g. the model village and which families they visited). This attempt to maximise their currency was seen as entirely legitimate in a competitive market where inequality was seen as necessary for the currency to circulate. They tended to view their actions not as examples of 'gaming the system', rather, as being competitive, which for them were a necessary condition to continue to serve themselves and their beneficiaries (Banks \& Hulme, 2012). However, it could be argued that such strategizing locks up time and resources that could otherwise had been focussed on beneficiaries (Banks \& Hulme, 2012; Strathern, 2003).

It could also be argued that the competitive practices of NGOs to maximise currency is potentially at the expense of other NGOs who are not as proficient. For example, while the increased knowledgeability was empowering for Rural India, as they were able to develop legitimate knowledge claims for current and future donors, it was to the disadvantage of other relevant NGOs seeking funding. Nonetheless, this inequality is a necessary condition of power, and how one is positioned relative to its circulation matters a great deal.

In the grant-seeking market knowledge and expertise to demonstrate impact becomes positioned as the principle way to produce value. As such, we see a shift to increasingly complex impact models and frameworks, requiring increasing expertise to develop, and to evaluate them. Potentially this has a variety of unexpected outcomes. Resources are diverted to developing knowledge and expertise, rather than development activity, as such. Development activity shifts to those activities that can be made more amenable to the calculative practices. Projects become designed, from the start, to achieve high impact evaluation, rather than necessarily achieving improvements for the beneficiaries. Smaller NGOs that cannot develop such expertise become displaced by larger international NGOs that have the resources to enact IA, expertly. As Foucault (1980) suggested, knowledge and power is co-constitutive.

\section{The performativity of the governing technology}

We have illustrated in the previous section that rather than IA methodologies being objective or 
neutral, they operate within a specific political economy where inequality is central to its operation-that of neo-liberalism. What does this inequality do or enact? First, within such a political economy, it becomes enacted as a particular governing technology that connectsthrough a set of calculative practices - the aspirations of those who govern, with the detailed activities of those who are governed. These calculative practices transform quality into quantity. As quantity it renders comparable what is incomparable, and connects or relates what might not be connected or related, through quantification and tabulation (in a spreadsheet). Moreover, it also enacts a reversal, from quantity to quality. NGOs that do well in IAs are taken as 'good' developers, deserving of funding and investment.

Second, calculative practices function as an anti-politics machine Ferguson (1994, p. 256). They allow the regime of governance to engage in "extremely sensitive political operations...almost invisibly, under the cover of a neutral, technical mission to which no one can object" - what Ferguson calls an 'instrument-effect. ${ }^{2 \prime}$ IA purports to provide objective data that is the basis for equal and fair decisions. However, as it circulates this apparently objective knowledge, of demonstrated impact (or not), de/legitimises certain type of activities, and renders in/visible certain activities-especially, potentially competing activities and knowledge. Of course, most actors involved in the circulation know and understand this. It necessarily enacts unequal relations between actors as it circulates. It is exactly this implicit politics that makes the numbers circulate, and matter, for each relation in the network, differently.

Third, within this circuit of knowledge/power the enactment of particular subjects are possible. The donor is enacted as a knowledgeable and responsible manager of resources who is accountable, and can account for the 'worthiness' or 'impact' of his investments. The NGO staff become enacted as more or less experts at achieving and demonstrating impact (e.g. learning which impact cases to select). These practices can be dismissed as 'game playing' but only to a certain point. What makes these calculative practices persist is the deep-seated belief, by all the actors involved, that on some level, these numbers actually reflect reality-maybe not entirely appropriately, and maybe somewhat selectively-yet they do. This is their political power, disguised in seemingly objective calculations. As (Miller, 2001) suggests so succinctly: "what is counted usually counts."

\section{INSTITUTIONALIZING INEQUALITY: SOME CONCLUDING COMMENTS}

We want conclude by returning to the theme of the special issue-the relationships between inequality, institutions and organizational practices. As already stated, institutional theory has mostly examined inequality indirectly, and second, institutional work, where we most closely

\footnotetext{
${ }^{2}$ Miller (2004) makes the same argument, when discussing the development of management accounting. 
align our research, has thus far neglected pick up on Foucault's later work on governmentality, which, as we have tried to show, is very relevant.

Returning to our research questions, Figure 6 illustrates: (1) the role of impact assessment in shaping institutional inequality, and, (2) how these asymmetrical relations are enacted in everyday practice. We demonstrated and argued that calculative practices (understood within the frame of governmentality) translates the social institution of the neoliberal international development market into mundane organizational practices, in order to produce new domains of knowledge/power, which position the actors across development institutions in ways that facilitate the enactment of their own inequality, continuously and freely.

Our analysis has highlighted that the market as a social institution shapes the interests of actors working within donor and NGO institutions, and crucially how people came to be governed through and by their own interests-specifically through calculative practices. In the institutional literature on inequality, Albiston (2009) and Martin (2004), but also many others, suggest that the social organisation of meaning-through taken for granted categories, concepts, discourses, etc.-enact social institutions that are fundamental in understanding the way inequality becomes institutionalised. For example, Martin (2004, p.1266) argues that understanding gender as a social institution reveals some of the ways 'gender' is used to construct practices, social relations, rules, and procedures, unequally. In our case, the market functions as a social institution to organise institutional work practices within and between the NGO and the donor. The idea of the market as an institution is well established (especially in neoliberalism). Also, outside of neoliberalism there is a general acceptance of the market (or market forces) as a valid and legitimate way of organising society, even if it is not perfect (Callon, 1998; Sen, 1985). What is important to note here, is that the market for grant funding imagines all actors as more or less free and equal to choose how they participate-at least in principle, if not in practice. Differently stated: such a market imagines a state of "equal inequality" (Lazzarato, 2009) - that is, inequality is fundamental to competition, though all actors are equal in choosing how they participate. All the same, even if the market as a social institution is generally accepted as valid it is not obvious how to translate it into everyday organisational practices across the specific NGO and donor institutions within a grant seeking market.

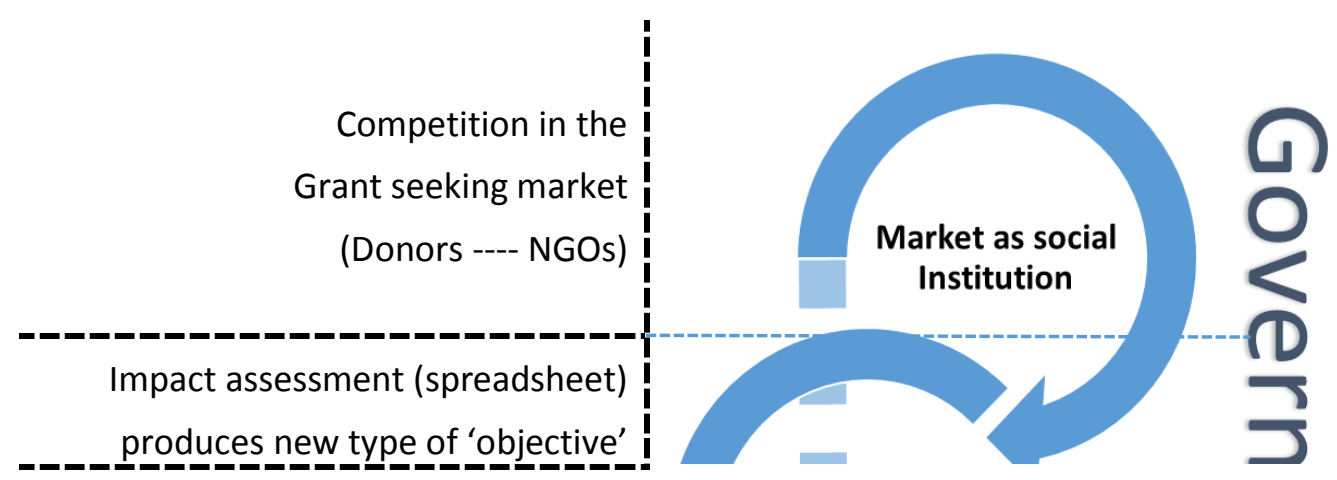




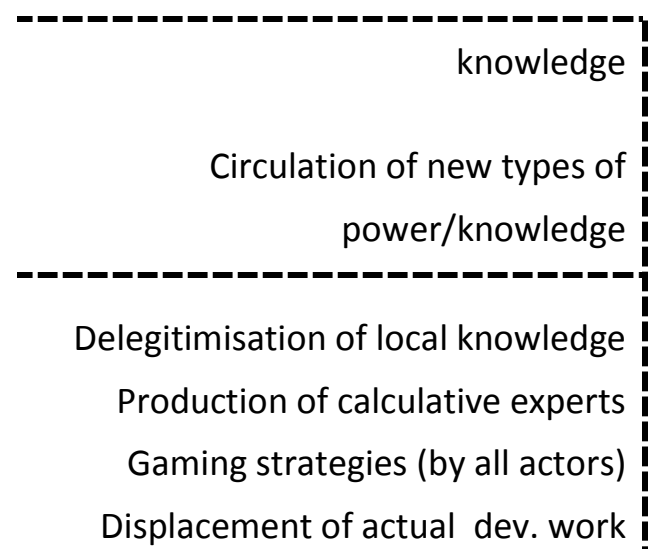

Figure 6: Institutionalizing Inequality: the role of calculative practices

Our research has shown that calculative practices are fundamental to this translation (Callon et al., (2007). As (Keeves \& Darmawan, 2015): 845) highlight "it is only when the numbers can be compared that markets are able to act as markets." What makes calculative practices such powerful translators is their assumed neutrality, their ability to render comparable heterogeneous entities, and, their calculability through a single figure (Miller, 2008). In our case, we saw how the IA functioned as a powerful technology to translate the strategic intentions of the donor, and indirectly, the social institution of the market into the daily lives of the NGO staff, the beneficiaries, etc. Its calculability enacted through a humble spreadsheet, converted development effort into percentages that can be compared, plotted, reported, and discussed. Donors themselves are also caught up in this, as they are accountable for their impact to their board of directors or in the case of government donors, the public. As a technology of power it does not act directly and immediately on others. Instead, it acts upon the actions of others; and in so doing presupposes the freedom for them to choose to act in one way or another. Based on the percentages in the spreadsheet they can focus on this or that development activity or areathey are free to choose as long as they can demonstrate impact in the terms of the knowledge/power enacted through the calculative practice. This observation is in line with Lounsbury and Crumley's (2007) call for institutional theory to guard against attending only to actors and not considering how cultural elements such as conventions and categories become embedded in wider meaning systems to shape organisational practices in significant ways. Impact assessment, as has been established in the rankings literature, shape actors behaviours and understanding of what is valued (Espeland \& Sauder, 2007; Espeland \& Stevens, 2008) . Through these calculative practices, a 'market logic' becomes imbedded in mundane organisational practices. Certain categories, conventions, and practices become seen as more legitimate than others-in terms of the knowledge produced, in and through the calculative practices. For example, resources are allocated in order to improve positions in the table, practices that achieve such improvements become more legitimate than others, and so forth. 
This is, however, only part of the institutionalisation process. In order to capture a fuller picture we also need to attend to the mundane organisational practices, not only in terms of what they are, but also in terms of what they do-that is in terms of their performativity.

Institutional inequality can be further understood with reference to regimes of inequality. Governmentality tells us that these calculative practices produce new types of knowledge; knowledge that can be used to make judgements and position activities and subjects in particular ways-especially unequally. It becomes difficult to question the legitimacy of this new knowledge, especially in the terms of the knowledge that has being delegitimised. For the NGO local knowledge about actual development was not expressible through the calculative practices. Expertise becomes defined in terms of this new knowledge, and so forth. What we see is the emergence of regimes of inequality, enacted through these new domains of knowledge. Impact assessment systems are good examples of this. Nonetheless, what makes them especially powerful is that they are freely enacted by the very persons they position unequally. In addition, they are very difficult to counteract because they are assumed to be neutral, and already embody a social institution assumed legitimate - the grant seeking market.

Of course, there are multiple opportunities for asymmetries within and between institutions located within the social institution of their market (e.g. within and between donors and NGOs). Actors are not necessarily positioned equally in the circulation of knowledge/power. Thus, what we tend to find is the development of what Acker (2006, p. 443) calls regimes of inequality, which she defines as: "loosely interrelated practices, processes, actions, and meanings that result in and maintain class, gender, and racial [and other] inequalities within particular organizations." We would want to be more specific and suggest that regimes of inequality are loosely interrelated practices, processes, actions, and meanings that result in the ongoing circulation of inequality, with significant consequences for those enmeshed in it. In our case this was evident in how the regimes of inequality saw the knowledge claims of the donor become dominant in the relations with the NGO, but also in how the NGO was seeking to reorganise so as to become more knowledgeable in aligning itself with the interests of the grant seeking marketplace. It also led to the NGO engaging productively with other potential donors though at the expense of other NGOs who were thus far unable to align their interests with those of the grant seeking market. Consequently, institutional inequality can be seen as an ongoing process of imbrication between regimes of inequality within and between institutions operating within a market. As regimes of inequality emerge, various actors attempt to place themselves in positions where they can maximise their interests. As these regimes of governance become more pervasive, and accepted 'as the way the world is,' these regimes of inequality may indeed become systemically embedded. These systemic circuits of inequality is the danger that we must attempt to make visible. Especially, since they are enacted through assumed neutral knowledge and legitimate 
institutions, and enacted freely by those caught up in these circuits of inequality.

What we see is the emergence of a regime of governance (a particular regime of truth) in which all the actors have become caught up in, and which becomes internalised by all involved as the legitimate (or only) way to act, properly and responsibly. This raises a number of implications for institutional inequality within and between international development institutions. First, that the overriding governmentality of the grant seeking market is likely to lead to the acceleration of more and more complex apparatus for identifying and analysing impact (Ciborra, 2006). This will extenuate some of the inequalities identified in this paper. As in Dar's (2014) case where the proficiency in English led to the recruitment of elite local staff, so too will the increasing complexity in impact reporting require that staff are expert in impact capture and reporting. As has been highlighted in other sectors, we see development workers being transformed into neoliberal 'careering' subjects often with their own career development in mind (Clarke \& Knights, 2015; Shore, 2008). While this may professionalise the sector, it simultaneously leads to the marginalisation of many development workers, especially those who lack the necessary education to participate. Second, there is a real danger that development will become understood as game playing. Game playing implies that development workers do not have faith in the effectiveness of the grant seeking market, but instead on securing funding and their careers (Shore, 2008:292). Further, game playing marginalizes direct and productive work with beneficiaries (Strathern, 2000). Third, localised qualitative knowledge will be further marginalised as it can be easily discredited in favour of quantifiable impacts. There is a real danger that impact assessment will subjugate and conceal much local development practice (Dar, 2008). Fourth, the increasing complexity and knowledgeability pertaining to impact assessment is likely to favour international donors and NGOs who have access to resources and expertise to develop and demonstrate impact positively. Fifth, what we see is the ongoing dominance of northern management knowledge that is sustained through the social institution of the grant seeking market.

To conclude, we acknowledge that our analysis and results are very much provisional, and situated in the Indian context, with a specific NGO / philanthropic donor interaction, and that research could also usefully consider the ways in which similar relations may hold more generally. This will include in-depth empirical research with a wide range of actors such as different types and sizes of donors and NGOs. More generally, we suggest that our framework of institutionalising inequality-as presented in Figure 6, may also inform accounts of institutional inequality in other sectors such as health and education. Central to such studies would be the way calculative practices produces knowledge that functions to de/legitimate certain practices and subject positions, which enact specific regimes of inequality, freely. While the regimes of inequality-enacted through calculative practices-will work themselves out differently, we 
suggest that there may well be many parallels. In relation to institutional theory specifically, our focus on mundane organisational practices is something that Lawrence \& Suddaby (2006) called for, especially in order to open up the specific details of how institutional control occurs (T. B. Lawrence, 2008), or in our case, how social institutions become translated into mundane organisational practices to produce regimes of institutional inequality. We would suggest that attending to governmental practices-such as calculative practices-is a very effective way of revealing institutionalisation processes because they function as invisible forms of power that people exercise over themselves, freely. Furthermore, we argue that governmentality allows us to understand how regimes of inequality continue to emerge and circulate in spite of their obvious danger. Clearly more work is needed. However, we would suggest our work indicates the potential for such endeavours.

\section{Funding}

This work is funded by the Digital Economy programme (RCUK Grant EP/G037582/1), which supports the HighWire Centre for Doctoral Training - (http://highwire.lancs.ac.uk).

\section{REFERENCES}

Acker, J. (2006). Inequality Regimes: Gender, Class, and Race in Organizations. Gender \& Society, 20, 441-464.

Acker, J. (2012). Theorizing Gender, Race, and Class in Organizations. In E. Jeanes, D. Knights, \& P. Y. Martin (Eds.), Handbook of Gender, Work and Organization (pp. 65-80). Chichester, England: John Wiley \& Sons.

Albiston, C. (2009). Institutional inequality. Wisconsin Law Review, 2009. Retrieved from http://papers.ssrn.com/sol3/papers.cfm?abstract_id=1708264

Alvesson, M., \& Skoldberg, K. (2000). Reflexive Methodology: New Vistas for Qualitative Research. London: SAGE Publications Ltd.

Banks, N., \& Hulme, D. (2012). The Role of NGOs and Civil Society in Development and Poverty Reduction (SSRN Scholarly Paper No. ID 2072157). Rochester, NY: Social Science Research Network. Retrieved from http://papers.ssrn.com/abstract=2072157

Banks, N., \& Hulme, David. (2012). The role of NGOs and civil society in development and poverty reduction. Manchester: Brooks World Poverty Institute. Retrieved from http://www.bwpi.manchester.ac.uk/resources/Working-Papers/bwpi-wp-17112.pdf

Barley, S. R. (2007). Corporations, Democracy, and the Public Good. Journal of Management Inquiry, 16, 201-215.

Belliveau, M. A. (2011). Engendering Inequity? How Social Accounts Create vs. Merely Explain 
Unfavorable Pay Outcomes for Women. Organization Science, 23, 1154-1174.

Bowman, N. A., \& Bastedo, M. N. (2009). Getting on the Front Page: Organizational Reputation, Status Signals, and the Impact of U.S. News and World Report on Student Decisions. Research in Higher Education, 50, 415-436.

Bowser, R. (2000). Racial bias in medical treatment. Dick. L. Rev., 105, 365.

Callon, M. (1998). Laws of Markets. Oxford; Malden, MA: John Wiley \& Sons.

Callon, M., Millo, Y., \& Muniesa, F. (Eds.). (2007). Market Devices (1 edition). Malden, MA: WB.

Callon, M., \& Muniesa, F. (2005). Peripheral Vision Economic Markets as Calculative Collective Devices. Organization Studies, 26, 1229-1250.

Chambers, R. (2010). A Revolution Whose Time Has Come? The Win-Win of Quantitative Participatory Approaches and Methods. IDS Bulletin, 41, 45-55.

Ciborra, C. (2006). Imbrication of Representations: Risk and Digital Technologies. Journal of Management Studies, 43, 1339-1356.

Clarke, C. A., \& Knights, D. (2015). Careering through academia: Securing identities or engaging ethical subjectivities? Human Relations, 18726715570978.

Clegg, S. (2010). The State, Power, and Agency: Missing in Action in Institutional Theory? Journal of Management Inquiry, 19, 4-13.

Collins, F. L., \& Park, G.-S. (2015). Ranking and the multiplication of reputation: reflections from the frontier of globalizing higher education. Higher Education, 1-15.

Contu, A., \& Girei, E. (2013). NGOs management and the value of "partnerships" for equality in international development: What's in a name? Human Relations, 18726713489999.

Dar, S. (2008). Real-izing development: Reports, realities and re-envisioning the self. In B. Cooke \& S. Dar (Eds.), The new development management: Critiquing the dual modernization (pp. 177 -198). London: Zed Books; Distributed in the USA exclusively by Palgrave Macmillan.

Dar, S. (2014). Hybrid accountabilities: When western and non-western accountabilities collide. Human Relations, 67, 131-151.

Davis, K., Fisher, A., Kingsbury, B., \& Merry, S. E. (Eds.). (2012). Governance by Indicators: Global Power through Quantification and Rankings. Oxford: OUP Oxford.

Dean, M. (2009). Governmentality: Power and Rule in Modern Society (2nd ed.). London; Thousand Oaks, CA: SAGE.

DiMaggio, P. J. (1988). Interest and agency in institutional theory. In L. G. Zucker (Ed.), Institutional patterns and organizations: culture and environment (pp. 3-22). Cambridge, MA: Ballinger Pub. Co.

DiMaggio, P. J., \& Powell, W. W. (1983). The Iron Cage Revisited: Institutional Isomorphism and Collective Rationality in Organizational Fields. American Sociological Review, 48, 147-160.

Dreyfus, H. L., \& Rabinow, P. (1983). Michel Foucault, Beyond Structuralism and Hermeneutics (Second edition). Chicago, Illinois: University of Chicago Press. 
Espeland, W. N., \& Sauder, M. (2007). Rankings and Reactivity: How Public Measures Recreate Social Worlds. American Journal of Sociology, 113, 1-40.

Espeland, W. N., \& Stevens, M. L. (2008). A Sociology of Quantification. European Journal of Sociology, 49, 401.

Ferguson, J. (1994). The Anti-politics Machine: Development, Depoliticization and Bureaucratic Power in Lesotho (New edition edition). Minneapolis: University of Minnesota Press.

Foucault, M. (1980). Power/Knowledge: Selected Interviews and Other Writings, 1972-1977. New York, NY: Vintage.

Foucault, M. (1982). The subject and power. Critical Inquiry, 8, 777-795.

Haney Lopez, I. F. (1999). Institutional Racism: Judicial Conduct and a New Theory of Racial Discrimination. Yale Law Journal, 109, 1717-1884.

Hansen, H. K., \& Mühlen-Schulte, A. (2012). The power of numbers in global governance. Journal of International Relations and Development, 15, 455-465.

Hardy, I., Heimans, S., \& Lingard, B. (2011). Journal Rankings: Positioning the Field of Educational Research and Educational Academics. Power and Education, 3, 4-17.

Hayes, N., \& Westrup, C. (2012). Power/knowledge and impact assessment: creating new spaces for expertise in international development: Power/knowledge and impact assessment. New Technology, Work and Employment, 27, 9-22.

Huffman, M. L., Cohen, P. N., \& Pearlman, J. (2010). Engendering Change: Organizational Dynamics and Workplace Gender Desegregation, 1975-2005. Administrative Science Quarterly, 55, 255-277.

Keeves, J. P., \& Darmawan, I. G. N. (2015). Philosophical and Pedagogical Underpinnings of Globalisation and Education. In J. Zajda (Ed.), Second International Handbook on Globalisation, Education and Policy Research (pp. 817-837). Springer Netherlands.

Lawrence, T. B. (2008). Power, Institutions and. In The Sage handbook of organizational institutionalism (p. 170).

Lawrence, T.B. and Suddaby, R. (2006). Institutions and Institutional Work. in S. R. Clegg, C. Hardy, T. B. Lawrence, \& W. R. Nord (eds.) Handbook of Organization Studies, 2nd Edition, pp. 215-254. London, Sage.

Lawrence, T., Suddaby, R., \& Leca, B. (2011). Institutional Work: Refocusing Institutional Studies of Organization. Journal of Management Inquiry, 20, 52-58.

Lazzarato, M. (2009). Neoliberalism in Action: Inequality, Insecurity and the Reconstitution of the Social. Theory, Culture \& Society, 26, 109-133.

Lounsbury, M., \& Crumley, E. T. (2007). New Practice Creation: An Institutional Perspective on Innovation. Organization Studies, 28, 993-1012.

Martin, P. Y. (2004). Gender As Social Institution. Social Forces, 82, 1249-1273.

Miller, P. (2001). Governing by numbers: Why calculative practices matter. Social Research, 379396. 
Miller, P. (2004). Governing by Numbers: Why Calculative Practices Matter. In A. Amin \& N. Thrift (Eds.), The Blackwell Cultural Economy Reader (pp. 179-189). Blackwell Publishing Ltd.

Miller, P. (2008). Calculating Economic Life. Journal of Cultural Economy, 1, 51-64.

Miller, P., \& Rose, N. (1990). Governing economic life. Economy and Society, 19, 1-31.

Morrissey, J. (2013). Governing the academic subject: Foucault, governmentality and the performing university. Oxford Review of Education, 39, 797-810.

Mühlen-Schulte, A. (2012). Full faith in credit? The power of numbers in rating frontier sovereigns and the global governance of development by the UNDP. Journal of International Relations and Development, 15, 466-485.

Munir, K. A. (2015). A Loss of Power in Institutional Theory. Journal of Management Inquiry, 24, 90-92.

Pollock, N., \& D'Adderio, L. (2012). Give me a two-by-two matrix and I will create the market: Rankings, graphic visualisations and sociomateriality. Accounting, Organizations and Society, 37, 565-586.

Rankin, K. N. (2001). Governing development: neoliberalism, microcredit, and rational economic woman. Economy and Society, 30, 18-37.

Riddell, R. C. (2008). Does Foreign Aid Really Work? (1 edition). Oxford University Press.

Roberts, S. M., Jones III, J. P., \& Fröhling, O. (2005). NGOs and the globalization of managerialism: A research framework. World Development, 33, 1845-1864.

Rose, N. (1998). Inventing Our Selves: Psychology, Power, and Personhood. Cambridge: Cambridge University Press.

Rose, N., \& Miller, P. (1992). Political Power beyond the State: Problematics of Government. The British Journal of Sociology, 43, 173-205.

Sauder, M., \& Lancaster, R. (2006). Do rankings matter? The effects of US News \& World Report rankings on the admissions process of law schools. Law \& Society Review, 40, 105-134.

Sen, A. (1985). The Moral Standing of the Market. Social Philosophy and Policy, 2, 1-19.

Shore, C. (2008). Audit culture and Illiberal governance Universities and the politics of accountability. Anthropological Theory, 8, 278-298.

Strathern, M. (2000). Audit Cultures: Anthropological Studies in Accountability, Ethics and the Academy. Routledge.

Strauss, A. L. (1987). Qualitative Analysis for Social Scientists. Cambridge: Cambridge University Press.

The Global Fund (2011) The Global Fund Strategy 2012-2016: Investing for Impact. Retrieved from http://www.theglobalfund.org/documents/core/strategies/Core GlobalFundStrategy20122016 Strategy en/.

Walsham, G. (1995). Interpretive case studies in IS research: nature and method. European Journal of Information Systems, 4, 74-81. 